\title{
Circumcision: Part II, Is Abraham the Patriarch only of Jews?
}

\author{
Ilia Brondz \\ Norwegian Drug Control and Drug Discovery Institute (NDCDDI) AS, Ski, Norway \\ Email: ilia.brondz@gmail.com
}

How to cite this paper: Brondz, I. (2020). Circumcision: Part II, Is Abraham the Patriarch only of Jews? Voice of the Publisher, 6, 18-30.

https://doi.org/10.4236/vp.2020.62003

Received: May 11, 2020

Accepted: June 15, 2020

Published: June 18, 2020

Copyright $\odot 2020$ by author(s) and Scientific Research Publishing Inc. This work is licensed under the Creative Commons Attribution International License (CC BY 4.0).

http://creativecommons.org/licenses/by/4.0/ (c) (i) Open Access

\begin{abstract}
In previous paper Circumcision: History, Scope, and Aim: Part I (Brondz \& Aslanova, 2019), was clearly presented by archeological and mythologic-historical evidences that custom of circumcision existed in Ancient Egypt for thousand years or more before Abraham's time. It also was evidence from Semitic mythology that God Il or El (abbreviation for ('Ēl or 'Il, Hebrew: אל; Syriac: Arabic: إلى : Romanized: ilu) is a Northwest Semitic word with meaning is "God", "Lord" or "Deity". God Il have appeared in Northwest Semitic tradition from Ugarit (maybe even earlier from the one of Phoenician traditions). The word 'ila, is the derivative form the old Akkadian and has roots in the Proto-Semitic archaic biliteral '-1, meaning "God". The Hebrew form אל word meaning God, it could be used for any God, including Hadad, Moloch, or Yahweh. The name Ėl, used in the singular, it means the supreme God, and by this it is referred to Yahweh. Yahweh for Jews is the supreme God, because other gods are supposed to be either nonexistent or insignificant, even they are existing. Yahweh have not denied existence of other Gods or Goddesses. Semitic Gods or Goddesses had not required from their followers to be circumcised before it has happened with Abraham. Abraham was circumcised, if he was at all was circumcised, by the order of God Il or El, or other Semitic Gods or Goddesses. In the present paper will also be explained the real meaning Goi (גוי), presented analysis will support the theory why the choice of Abraham as Patriarch by Jews was done, why in the Old Testament was described his circumcision and the arguments in opposition to the description of Abraham's circumcision by order given by God Il or El, or other Semitic Gods or Goddesses at the time. The name used in the paper Abram and Abraham is referred to the same man as it is in the Torah, or in the Bible, or in the Koran.
\end{abstract}

\section{Keywords}

Patriarch of Jews, Abraham, Goi (גוי), God Il or El, Yahweh 


\section{Introduction}

In the present time people look on all events and things through the prism of existing climate, geography, traditions, linguistic definitions, numerical measurements and mentality. All this was different in prehistoric or biblical time and the time of the Old Testament, the Bible, or the Koran. It was mentioned in (Brondz, 2017) the end of the Würm glaciation, approximately 6000 years ago when the cold weather began to be warmer and warmer up to present time and many changes are occurred. The climate changes were and are main driver in human evolution and technical progress from Neolith to the present time. The climate change has triggered and has coincided with appearance of first permanent settlements and cities on the Earth. About 3500 BC in China, 4000 BC in Mesopotamia, 6000 $\mathrm{BC}$ or even earlier at 10,000 BC in Canaan (Israel) appeared one of the first permanent settlement. The spores of first Jericho settlement were discovered in Israel (Canaan). Jericho is very important in this discussion not only because she is mentioned in the Old Testament as the first city in Canaan conquered by Joshua, but because the other cities were mentioned in time when Jericho existed, or in time Jericho has been abandon. Jericho has a history than she was several times abandon and re-erected after significant time of non-existence.

Like in the time which describes arrival and domiciling of Abram in Canaan she was not mentioned. Jericho as domiciling place has history of settlement dating back to 10,000 BC (Mithen, 2006). The Wall of Jericho was suggested to date to approximately $8000 \mathrm{BC}$ (Kenyon \& Holland, 1981). The famous tower of Jericho which is $10 \mathrm{~m}$ high can be seen today in the vicinity of today's Jericho. However, the tourists will be surprised then they come to the place and can see only a hole $20 \mathrm{~m}$ deep in the ground. Only then they are looking in this hole, on the bottom of the hole they can see the $10 \mathrm{~m}$ high tower. How it could happen that this tower, which is $10 \mathrm{~m}$ tall from the basement, was covered with $20 \mathrm{~m}$ of soil? The geological changes in the region were of gigantic scale.

\section{The Geographical and Climatic Differences}

The other important things are environment, climate, landscape and biosphere. The traditions and customs also will play the indicators for support of the presented theory.

The area of the Dead Sea has crumbled on $1 / 3$ today in comparison to the areal which was in the beginning of $20^{\text {th }}$ century. In the beginning of $20^{\text {th }}$ century there were two lakes in the vicinity of Golan plateau and mount Hermon in Israel, the Lake Gennesaret and the Lake Hula. Today, instead of Lake Hula is a valley. How these two lakes have looked in the Biblical time is not clear, or may be instead of two lakes were only one big, which was a Sea of Gennesaret? In the Bible the lake of Hula has not been mentioned, nether in the Old- or New Testament, or in Roman's accounts of the war with Jews the lake Hula has not been mentioned. 
The Sinai Peninsula 4000-3500 BC was not the terrible dry desert as today. It could be more sustainable for life, f. ex. as in our time the African savannas are. This can explain the traffic through Sinai at the time of Abram or Jacob and the 40 years dwelling in Sinai by Jews under Moses leadership. The flora and fauna of Sinai Peninsula could be quite different from today's Sinai. In contrast with today situation the southern region of Israel the land of Canaan (the southern region of Jordan River Plain) was well-watered and green Genesis 13:10. Many permanent settlements are named in the Torah in this region as: Sodom, Gomorrah (Hamara), Admah, Zeboim, and Bela.

\section{The Biosphere and Customs}

Abram came out of city Ur in Chaldea. He came out not alone and not as the leader of the clan or family. He comes out of Ur as a son of Terah. Terah is the man who had decided to come out of Ur and proceed to Canaan. Who ordered Terah to do this? Is it possible that the God Il did this? Terah could travel by the shortest way through the desert. This way for travelers without camels (Brondz, 2018a) as the luggage carriers was impossible to overcome. Terah had chosen the way which later has been used by Hyksos (Redford, 1992), (Holy Bible, King James Version, 2010) and (The Torah, 2010).

Domestication of camels is believed to happened in Africa around 3000 BC and in Bactria in Central Asia around 2500 BC (Brondz, 2018a). The domestication of camel has occurred approximately at $2500 \mathrm{BC}$ in Chaldea. As the first point of the counting time down this point at $2500 \mathrm{BC}$ should be accepted by supposing that Terah came out from Ur before the domestication of camels in Chaldea.

The camels were mentioned in Christen translation of the Torah (Holy Bible, King James Version, 2010): "He treated Abram well for her sake, and Abram acquired sheep and cattle, male and female donkeys, menservants and maidservants, and camels." and other translations of the Torah and even in the Torah, in the Genesis 12:16. But should be remembered that the Torah which we know today has been composed in Babylon's slavery. Up to Moses's days and may be even later Jews have not knowledge about camels and have not used them. Support to it is presented in Exodus 13:1 - 13:3 "The Lord said to Moses, "'Consecrate to me every firstborn male. The first offspring of every womb among the Israelites belong to me, whether man or animal." Exodus 13:12 and 13:13 “.. ${ }^{12}$ you are to give over to the Lord the first offspring of every womb. All the firstborn males of your livestock belong to the Lord.", and " ${ }^{13}$ Redeem with a lamb every firstborn donkey, but if you do not redeem it, break its neck. Redeem every firstborn among your sons". Because it was direct command of the Lord self, the command was one of the decisive and obligate laws and duties of the Israelites. The scrutiny of words should be clear, no less or not more must be done. To the Lord was not possible sacrifice the not firstborn or not kosher animals. The camels were not mentioned at all. Beside of this the camel is not kosher animal. 
The camel could not be sacrificed or redeemed to the Lord, in contrast to the donkey which could be redeemed. The products of camels were not kosher, not the meat, milk, wool or skin and by this should not be used by Jews as the food or as the clothes. In today's Israel the kashrut's law for orthodox Jews covers even the toilet washing liquids, it is difficult to imagine that in Moses's time or maybe in time of his predecessors' (if they were not the pagans) the kashrut's law was different and the camel was a kosher animal.

Later in Genesis 20:14 "Then Abimelech brought sheep and cattle and male and female slaves and gave them to Abraham...", no word is mentioned about the camels.

It should be special pointed out that on the walls of tomb of an official from the Twelfth Dynasty Khnumhotep II, on the picture of entrance of Asiatic peoples (Semites) has been depicted only gazelle, goat and donkey (Bard, 2008) as the domesticated animals. The camels have not been mentioned in the archaeological or mythological documents of this period and in the Bible in the description of Exodus (se in Exodus 13:12 and 13:13). Egyptians were very realistic in their paintings on the walls of the tombs, because these paintings were the messages to their Gods and Goddesses of Egypt and should protect the dead on the God's trail. All the mentioning of camel in the Old- or the New Testaments are the Jewish fables from the time of Babylon's slavery or fables of Christian's Greek composers of the New Testament. Jews must not use non-kosher products nether for food nor for clothes or shoes (Brondz, 2018b).

Such fable as in Genesis 31:34 "Now Rachel had taken the household gods and put them inside her camel s saddle ..." looks very suspicious, especially after absences of mentioning of camels in Genesis 20:14 before and in Exodus 13:12 and 13:13 after this. All paintings or stories about Kings David or Solomon are riding on camel are imagination of the Middle age's authors and fables without any historic background, as the story about the clothes prepared from camel wool of Jon the Baptist told in the Evangels. Such stories are weeds among the crops. Even Alexander the Great-King of the Ancient Greek Kingdom Macedonia up to his death or the Romans up to war with Jews had not knowledge about the horse's saddles. The saddles as well as trousers had become known hundreds of years after this time, from the Middle Asiatic nomads. It is unwise to believe that Abram, Isaac, Jacob or one of Pharaohs have dressed on in trousers, as believe that Rachel, Abram, Isaac, Jacob or one of Pharaoh have ride on the camel or possessed a camel.

\section{The Time and Customs}

On the walls of tomb of a Twelfth Dynasty official Khnumhotep II who lived in time of pharaoh Senusret II there was depicted entering in Egypt a group of Asiatic peoples. It had happened approximately at 1900 BC (Bard, 2008). This is giving to us the second time point at $1900 \mathrm{BC}$. Terah had choose the way which was later have used by Hyksos (Hyksos settled in the north-eastern Egypt some 
time before 1650 BC) (Redford, 1992). Those two time points between 2,500-1,900 BC and 1700-1650 BC well correlate with stories from the Old Testament. The date about 2500-1900 BC is more correct than other for supposing the time when Terah had started his journey to Canaan.

Terah had chosen the way to the North along the river and after this to the South along the Mediterranean Sea shores. It was naturally to stop at city Haran (Holy Bible, King James Version, 2010), (The Torah, 2010) because the supreme God in Ur and supreme God in Haran was the same, the God 'Ilu (the Uppermost God of Sky, the creator of Sky and the Earth) God Il or El. Terah and family have needed some time of repose in their journey. Terah and his family were nomads, they have not dwelled in the city, but they have dwelled in vicinity of city, in the surrounding fields. However, they have paid taxes to the lord of Haran as they did it in Ur for to have the permission to use the land, water, for protection, and for permission to pray to the God 'Ilu (God Il or El) in the city's Temple.

The age of Terah and members of his family is a questionable problem. Up to Moses the Biblical age of people have been suspicious long living span, if it should be as 365 day in the year. However, we do not know the reel span of the year at that time. Some ancient myths can give us a clue. Adonis (a God) was killed by wild boar, Adonis (Greek: 'A $\delta \omega v i \varsigma$, pronunciation: [ádo:nis]) was killed by a wild boar and his death has symbolized the rotation of seasons from autumn through winter and, later, a rebirth through spring and summer (Brondz, 2018b). The Biblical predecessors of Terah could count every season in their life as the unit. The Terah and members of his family were nomads and could also count every season in their life as the unit. In this case the life of Terah and members of his family looks to be very short. However, it can explain the span of lives of the predecessors of Noah and for Noah himself. However, the other myth can cast the light in correct direction, the myth about Proserpina (Roman) Goddess who was forcible abducted by the god of the Underworld, God Pluto (Roman, Latin: Plūtō). The Deities have rescued Proserpina's freedom by agreement with Pluto. By this agreement she should live half a year at Underworld (this was explanation of cold periods like autumn and winter) and she should live half a year in the freedom on the surface of the Earth (this was explanation of warm periods like spring and summer). Carefully examination of archeological evidences can give explanation that in the early time than the society were based on collecting food and hunting the seasons played significant role and could be the measure for time units (spring, summer, autumn and winter). However, later people had started to live as semi nomads (instead of been as only the hunters and collectors) as Terah and his family were. The more suitable division for the time units were connection to the periods of migration to the sheep's grassland (Terah and his family were shepherds), in the spring and summer (in warm weather periods) and in the autumn and winter to return (in cold weather periods) to harvest the crops and to live in vicinity of settlement. By this at the time for Terah four-time units had merged in two periods-these two time's units had an importance. 
Later these two time's units had merged for us as only one-time unit of the 365 days-it is the one year for us. By this the age of 75 at which Abram followed Terah from Ur can be corrected to 37.5 and Abram's age 90 of his possible circumcision can be corrected to 45. Abram's age of first travel to Egypt is somewhat before 45 years. This explains the interest of Pharaoh in Sarah, because she could not be a granny at this time, she was a relatively young lady.

The other reason about the long lives of patriarchs described before Abraham is in the fact that Jews have used the letters of the alphabet instead for numbers. Before it has existed several different systems of numbering. Our system of the numbers is known to us as positioner system of Arabic numbering. However, Arabic numbers were only transferred to Europe through the Arabs' merchants. Arabs have learned these numbers from Hindus. Hebraic and Arabic script are written from the right to the left, however most of the known scripts are written from the left to right, the numbering also is written from the left to right. In Hebraic and in Arabic, it is a significant challenge to combine the texts with mathematics. In Mesopotamia was used cuneiform (arrowhead) characters and numbering, the translation these to Hebraic letter-numbering could lead to some mistakes as later translation from Hebraic system of letter-numbering to Roman stile of numbering. The zero was absent in both systems, the systems were not the positioner systems. This could be the sources of mistakes.

However, the long lives of patriarchs could have a real and natural explanation also. All prehistoric organisms as most of plants and dinosaurs had large bodies because they had ability to grow up and increase body mass unlimited in time. Life was not limited genetically as it is for nearly all creatures today. Prehistoric creatures had not possessed the gen which had limited the grow and lifetime as in most of fishes' in shark family even today. The prehistoric people could have the transitional situation in their genetics. In the Bible often life limit for after Abraham's people is mentioned around 120 years. The scientific limit of lifetime for people today depends from gender and race and it is somewhat between 120 and 160 years depending from the time of ossify of the skeleton.

In case if the story of the traveling to Egypt was a real one, then in Egypt Abram and all male-members of his family including the slaves should be circumcised as the Egyptian's law had commanded this. They must be obedient to Egyptian's law for to receive permission to stay for a while in Egypt. For this reason, in the Old Testament exists the fable that Abram was circumcised at 99 (correct at about 50) years. The story is presented in Genesis 17:9 - 17:13.

This fable that Abram was circumcised at 99 (corrected at 50) years contradicts itself. The fable that Abraham was the first male who was circumcised is only a fable, this fable is obviously not correct.

In the Genesis 13:4 in Abram Rescues Lot is stated that: " ${ }^{17}$ After Abram returned from defeating Kedorlaomer .. ${ }^{18}$ Then Melehzedek king of Salem brought out bread and wine. He was priest of God Most High, and ${ }^{19}$ he blessed Abram, saying, ...". This short paragraph includes very much information which is important for this discussion and as support to the hypothesis. The name and posi- 
tion of Melehzedek have importance. In (Brondz \& Aslanova, 2019) was presented that most of the ancient names was meaningful and was the combined names-theophoric names (Gray, 1964). It is the same for name "Melehzedek". This name is combination from two words: Meleh and zedek. Hebraic meanings for Meleh is angel the synonym to envoy of Lord, (later it became a title of king), zedek is just-or pious person. His position was the King of Salem. He also was in a position of "priest of the God Most High". In the cities of Ur and Haran supreme God was the God Il or El the God Most High, without of any debt he was the priest of God Most High in Salem. If the Abraham was the first male who was circumcised by order of God Il or El, that means the priest of the God Most High (priest of God Il or El) was not circumcised. In the Torah the circumcision is the act of contracting and confirming covenant with God/Lord the God Most High. How Melehzedek could be one who was not circumcised to be the priest of the God Most High without to be in covenant with the God Most High? How he Melehzedek could be one who was not circumcised to bless Abram in name of the God Most High? Is it possible that the God Most High who has gave the order to Abraham in the sake to fasten covenant with the God Most High to undergo circumcision, but He did not have ordered Melehzedek to fasten the covenant by circumcision with the God Most High and despite of that Melehzedek was not circumcised, He did him His priest? This is showing the nonsense and fabulousness of the statement that Abraham was the first circumcised male. It also gives the basis to doubt that the story about the circumcision of Abram which presented in Genesis 17:9 - 17:13 is original.

Another argument that the demand to be circumcised was not the obligate demand to be in covenant with the God Most High, God Il or El, and that Abram before he got in Egypt was not circumcised. Lot and his offspring were also circumcised in Egypt (offspring of Lot are Jordanians and they are circumcised), despite that by the time describing Abraham's circumcision in Genesis 17:1 17:27 Lot was already separated from Abraham's family.

Moses is the man who introduced the mass circumcision among the Semites and converted them to monotheists-followers of Yahweh and by this did them to Israelites.

\section{The Time and Geographical Evidences}

The information which also could be recovered from the paragraph above is that the name of city is Salem. Salem is the city of Jerusalem. In Hebraic it is Ir u shalaim, meaning: Ir-city, $u$-of, shalaim or Salem (name of one of Gods in the pantheon of the Northwest Semites), the -im is the plural or in old days means the highest respect. The Hebraic has not the capital letters, and it cannot be written Lord or God as in other languages to show the respect by starting the words by capital letter. Because of this to show the respect in Hebraic was used Elohim instead of El. The ending -im is a sigh of plural, but it also is a sign for the respect. For the same reasons in Arabic it is used Allah instead of Al. 
This fact of existence of city Salem has significance as support to existence of city Jerusalem in time of Abraham and for other aspects of the discussion.

In the Genesis 13:4 in Abram Rescues Lot has been presented important evidences about the cities of Gomorrah and Sodom at the time of Abram's domiciling in Canaan. The literation "Gomorrah" is wrong. The correct literation should be close to Hebraic and should be as "Hamara" it is supported by the text of the Torah itself.

Meaning of this name Hamara is $\mathrm{Ha}$ (distinct article) and mara (bitter). Alliance of five cities were mentioned in the Torah: Sodom, Gomorrah (Hamara), Admah, Zeboim, and Bela. It is important point for determination of Abram's domiciling in Canaan as existence of several cities as Salem (Jerusalem), Sodom and Gomorrah (Hamara) were existed at that time, however Jericho was deserted. Sodom and Gomorrah (/'spdəm ... gə' mprə/) were two cities mentioned in the Book of Genesis (Schwartz, Loebel-Fried, \& Ginsburg, 2007) and in the Hebrew Bible (Metzger \& Coogan, 2004) in the New Testament, and in the Koran and the Hadith. It is first time was documented and mentioned permanent domicile of Semite Lot as a city dweller.

Facts about many other existed cities as f. ex. Damascus have been named in connection to the Terah's and Abram's travel to Canaan. These facts can support or contradict truth or fables in the story about Abraham and Abraham's domiciling in Canaan.

\section{Abraham's Offspring}

For better understanding of the hypothesis, the short excursion in history of relation and juridical status in Jewish family must be given. In medieval time in Europe from 1348 to 1351 the Black Death epidemy caused wide number of deaths. Especially in German' kingdoms and Bohemia and elsewhere. Jews were accused in this epidemy. Jewish's persecutions and massacres during the Black Death were a series of violent attacks on Jewish's communities all around Est-, Central- and West Europe. Most of them had an aim to rob the Jewish's goods and rape the Jewish's women. Many women were pregnant after these ferocities (Zahler, 2009). Rabbis have decided to declare and state the new law. In the new law was the way to avoid the problem with appearance of bastards. By this law the definition of the belonging was motherhood. In Jewish's families the birth of all children from the married Jewish's mothers are the Jews and all are welcome as the Jews, independent of the father's origin and religion. The males must be circumcised on the eighth day and questions about their origin should not be asked. In the married couples the Jewish man is always a father of the child. Later this law was misused by Nazis, they had defined all born from the Jewish mothers as the Jews unrelating to fatherhood or religion despite in Christianity the origin of child is established by fatherhood and religion. This new Rabbinic law was in deep contradiction to existed customs and rules in Torah, however this law saved many couples, women and children from community's prosecutions and the communities from destruction. 
In Torah only seldom names of wives of the patriarchs or other historical individuals are mentioned. The name of the Kain' wife, or wives in all offspring's in his line up to Lamech are not named Genesis 4:17 - 4:18. The same tradition was followed from Seth the Adam's son up to Noah and from Noah to his sons Shem, Ham and Japhet Genesis 5:1 - 5:32. Up to the time of the Jewish persecutions and massacres during the Black Death the fatherhood was decisive in the claiming of Jewish origin for the child. Motherhood' line of the King David, Prophet Samuel who anointed King David is highly questionable and hidden in the texts of script, however the motherhood of King Solomon is clearly not Jewish. His mother was a Hittite, but this had not prevented him to become the King of Israel as a Jew. In the time of Abraham, the rights of wife and her maidservant-concubine was slightly different, wife had the higher status, however the children, especially the sons of wife or concubine had the same rights and privileges. The eldest son should possess the father's blessing without no matter he was born by the wife or by the concubine. Hagar was a maidservant of Sarai; Hagar was a concubine of Abraham. The Great Prophets Moses and Muhammad are allowing the polygamy in the Torah and the Koran (respectively). Ismael was the firstborn son of Abraham; he was circumcised by Abraham himself (by this he was blessed by the God Most High, Yahweh, Allah, (if we should believe to Torah)); he was beloved son; he was the important one. Isaac was born the years after Ismael. Isaac also was blessed through Abraham by the God Most High, Yahweh, Allah). The Kaaba was built by Abraham and his son Ismael in Mecca as accepted by the Islamic tradition, in the Koran, Hadith and by Prophet Muhammad's statement about the Kaaba (Kaaba, also referred to as al-Ka'bah al-Musharrafah (Arabic:

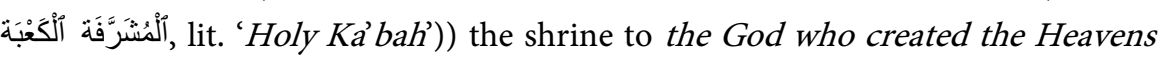
and the Earth and all between them, the God of Abraham, Ismael, Isaac and Jacob. It was the shrine to Allah the God Most High and Yahweh.

After the death of Sarai at Kiriath Arba (Hebron) "Abraham took another wife, whose name was Keturah" Genesis 25:1. Without of debt Keturah was a Hittite by nationality, and pagan by belief, because no other free females were around. From Keturah had been born to Abraham many sons: Zimran, Jokshan, Medan, Midian, Ishbak and Shuah. The sons of Keturah had born many other people. Ismael, Isaac and all sons in line of Keturah are Goi (גוי) (גוים). By definition the Jews and Arabs are sons of Ismael and Isaac. Both Ismael and Isaac are sons of Abraham who received the blessing. Abraham was blessed by the God Most High to become Genesis 17:4

“אני הנה בריתי אתך והיית לאב גוים". The English translation from Hebrew (Holy Bible, King James Version 2010) is: "You will be the father of many nations", however, the correct word to word translation is: "I (the Lord) hear I had created you to be the father of Goim (והיית לאב גוים)".

\section{Jacob His Family and His Story}

All what is connected to Jacob is very significant for the theory and presented discussion. Isaac the father of Jacob was married Rebekah not at the age of forty years, 
but at twenty, what is a normal age for marriage. Rebekah was a daughter of Aramean Bethuel. Bethuel is characteristic theophoric name (Beth-house, $u-o f$, el-God El) which gives a perception to belonging the man to Semites and adherence to believers of God El the God Most High. Isaac born two sons Esau and Jacob. Esau was the eldest. It is the parallel to Ismael and Isaac. In Genesis 26:1 26:25 Jacob's journey was nearly the duplicate of the Abraham's travel to Egypt written in Genesis 13:10 - 13:20, however it was someone extended story. Some additional information can be obtained from the presence of Philistines in the region at the time of Isaac and even in the time of Abraham. Relation of Philistines toward Abraham and Isaac as it described in Genesis was friendly. Beside of Genesis is exists archeologic evidence from the time of Ramesses III the Pharaoh of the Twentieth Dynasty in Ancient Egypt, his reign was at 1,186-1,156 BC. In Southern-West of Canaan region were five cities-kingdom Gaza, Ashkelon, Ashdod (correct should be Azot), Ekron, and Gath in these have lived Philistines-known as "the Sea People". The Philistines have lived on the coast of Canaan at list from the $12^{\text {th }}$ century BC. Relations between Isaac and the King of Gerar Abimelech were good. The name Abimelech (theophoric name Abi (my father) and melech (king) is pointed on the Semitic tradition. If Isaac has met Abimelech this points to the dates before reign of Ramesses III at 1,186-1,156 BC. Abimelech obviously was not circumcised despite of his Semitic name. All this story is slightly suspicious because it is duplicating the similar story about Abraham.

In the Torah the writers have tried to impose the belief about early timepoint of circumcision of Jews. In Genesis 34:1 - 34:31 Dinah and the Shechemites strange things were told: The King of Shechem bear name Hamor translation is Donkey very strange and offensive name. Dinah is a daughter of Jacob and Leah; Dinah also is a sister to Simeon and Levi. Son of King by name Shechem took Dinah and raped her. All brothers of Dinah were greatly offended by this. Hamor has negotiated with Jacob the peace through marriage agreement between his son Shechem and Jacob's daughter Dinah. The conditions were pushed by Diana's brothers: "all males in the City must be circumcised as Jacob's men". Later Simeon and Levi killed all people of the City because Dinah has been defiled. It is despite of that all men in the City were circumcised and peace was negotiated.

The story of Dinah in the Torah has only one aim. The aim is to state that Jews were circumcised already at Jacob's time and even before. After Genesis 34:31 Dinah's name disappears from script and has not been mentioned among the names of the tribe's- or family's-commers from Egypt. Her offspring were not named among the followers of Moses in Exodus as they have not existed at all. Dinah's story is a pure propaganda with the aim to implant in the mind that Semites were circumcised before they have attended Ancient Egypt in the Jacob's time.

Only Moses by Yahweh's laws imposed the obligation to circumcise all the men who were and are Yahweh's followers. The Semites, non-Semites and slaves who followed Moses, by Yahweh's order given to Pharaoh, the order: “Let my 
people go!" these who came out of Egypt's slavery were circumcised in Sinai and by this they became the Jews.

\section{Abraham Patriarch of Goi (גוים) -The Patriarch of Jews and Arabs}

Among the Jews and non-Jews persists a wrong interpretation about meaning of term Goi (גוים) or Goim (גוים). It is the source of many bad-feelings and even accepted among non-Jews as insult.

Genesis 9 under the Sons of Noah has been written that Noah brought three sons: Shem, Ham and Japheth. Jews are part of Shem's family together with Arabs and some others. Ham and Japheth designated as all other people on the Earth. However, Shem's family has interdivisions. Abraham has been blessed by the God to be the father of Goim. Between Kain and Abraham were several generations of men up to Eber. The Hebraim (Jews) as Eber's offspring are closer to Eber. Jews could choose the Eber as Patriarch, but Eber was only the legendary personality without of distinct geographical connection and history. Abraham (is recognized by the Torah, the Bible) has received blessing from Melehzedek and more important he was blessed by the God Most High and become in Genesis 17:4 "אני הנה בריתי אתך והיית לאב גוים" the translation from Hebraic to English which sounds like "You will be the father of many nations" in (Holy Bible, King James Version, 2010). "גוים" direct translated from Hebraic to English as the word is "nations". Jews are the people among "גוים" "גוים" is not the insult it is a segment of the population on the Globe to which belongs Jews and Arabs and some others. However, all the people on the Earth without of exception received blessing through Abraham by the God Most High.

Abraham has distinct adherence by Jews (as Abraham's offspring's) as the anchor to the land of Canaan (Israel) through blessing of the God and through the material evidences of cave Machpelah (Hebraic: מערת המכפלה) which is the grave of several generations of Jewish Patriarchs. The same symbolic attraction Abraham has to Arabs (as Abraham's offspring's) as the anchor to the land of Canaan (Israel) through blessing of the God and through the material evidences of cave Machpelah the Abraham's grave (Arabic: الإبراهيمي الحرم). However, Lot's offspring's (Jordanians and Palestinians) and some other in the region are not the Abraham offspring's and they have not received in the possession from the Lord through Abraham the land of Canaan. Palestinians must decide if they are Arabs, then they are co-owners of Canaan (Israel), if they are the separate and distinct nation (f. ex. descenders of Lot) they have only blessing through Abraham's name as all nations on the Globe, but they are not the co-owners of Canaan (Israel), because they are not descends of Abraham, they are not the Goim (גוים).

\section{Instead of Conclusion}

In the Torah is at list eight words that have been used to name the Deity. Rabbi Samson Raphael Hirsch in The Pentateuch, Bereshith, Part I: Bereshith-Hayye Sarah has presented in the opening sentence: "א א בראשת ברא אלהים"-"In the 
beginning Lord created". He has explained that word אלהים one of names of

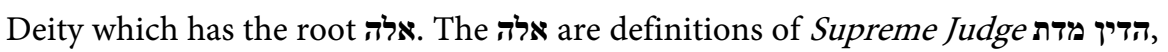
the God Most High, Allah. In did the spelling of אלה, is $A, L, A$. In Hebrew there is not exist the doubling of consonants. In Arabic in absence of the capital letters respect to God $\boldsymbol{A l}$ is expressed by $\boldsymbol{A l l a h}$, in Hebraic the respect to Deity is shown by addition to end of the word the imperial - - י The God Most High by this is expressed as אלהים.

Ismael and Isaac are sons of Abraham. Abraham is offspring of Eber. Eber is offspring of Sem. Offspring of Ismael and Isaac are Semites. Offspring of Ismael and Isaac are brothers. Offspring of Ismael and Isaac are Goim (גוים). Offspring's of Ismael and Isaac (Arabs and Jews) have equal blessing through Abraham from the God Most High, Yahweh, Allah to possess Canaan the land between Jordan River and Mediterranean Sea, the land of Israel.

Abraham has traveled thousand miles to build together with his son Ismael the shrine to the Lord the God Most High, Yahweh, Allah, the shrine Holy Ka'bah in Mecca.

With all my respect to Holly scripts during the many centuries all scripts were rewritten by men, and men had also heavily interpreted the texts. The only common ground for the Torah, the Bible and the Koran (Holy Bible, King James Version, 2010), (The Torah, 2010), (The Koran, The Holy Book of Islam with Introduction and Notes) only Ten Commitments are counting, these must be followed and observed. Only Yahweh gave to the bunch of Semites, non-Semites and slaves the freedom and land of Canaan in possession and created from Egyptian's slaves the nation Israel - שראל האומה.

\section{Conflicts of Interest}

The author declares no conflicts of interest regarding the publication of this paper.

\section{References}

Bard, K. A. (2008). An Introduction to the Archaeology of Ancient Egypt. Oxford, UK: Blackwell Ltd.

Brondz, I. (2017). To Be or Not to Be...? Part I: Is Global Climate Change a Future Reality? Voice of the Publisher, 3, 25-33. https://doi.org/10.4236/vp.2017.33003

Brondz, I. (2018a). To Be or Not to Be ...? Part III: Diesel versus Electrically Powered Cars. Voice of the Publisher, 4, 33-50. https://doi.org/10.4236/vp.2018.43004

Brondz, I. (2018b). Why Judaism and Islam Prohibit Eating Pork and Consuming Blood as a Food? Voice of the Publisher, 4, 22-31. https://doi.org/10.4236/vp.2018.42003

Brondz, I., \& Aslanova, T. (2019). Circumcision: History, Scope, and Aim: Part I. Voice of the Publisher, 5, 77-87. https://doi.org/10.4236/vp.2019.54006

Gray, J. (1964). The Canaanites (Ancient Peoples and Places). London: Thames \& Hudson.

Holy Bible, King James Version (2010). Zondervan. The Gideons International, in the British Isles, Lutterworth, England.

Kenyon, K. M., \& Holland, T. A. (1981). Excavations at Jericho: The Architecture and Stratigraphy of the Tell: Plates. British School of Archaeology in Jerusalem. London, 
British school of archaeology in Jerusalem, 1981.

Metzger, B. M., \& Coogan, M. D. (2004). The Oxford Guide to People and Places of the Bible. Oxford: Oxford University Press.

Mithen, S. (2006). After the Ice: A Global Human History, 20,000-5000 BCE (1st Harvard University Press pbk. ed.). Cambridge, MA: Harvard University Press.

Redford, D. B. (1992). Egypt, Canaan and Israel in Ancient Times. Princeton, NJ: Princeton University Press.

Schwartz, H., Loebel-Fried, C., \& Ginsburg, E. K. (2007). Tree of Souls: The Mythology of Judaism. Oxford: Oxford University Press.

The Koran, The Holy Book of Islam with Introduction and Notes, Translated by Palmer, E. H. (was first published in 1900), this edition first published in 2017 by Watkins, an imprint of Watkins Media Limited, London.

The Torah (2010). London: Kuperard.

Zahler, D. (2009). The Black Death. Minneapolis: Twenty-First Century Books. 